\title{
Penurunan Penggunaan Antibiotik pada Pasien Anak dengan Demam
}

\author{
M.M.Hapsari * , Helmia Farida**, Monique Keuter*** , P.J,van den Broek****, \\ Usman Hadi*****, Herawati $Y^{*}$, Anggoro DB Sachro*
}

\begin{abstract}
Latar belakang. Resistensi antibiotik saat ini menjadi problem dunia yang mencemaskan. Penggunaan antibotik secara berlebihan dan tidak rasional merupakan kontributor utama terjadinya resistensi antibiotik. Upaya mengubah pola peresepan antibiotik menjadi lebih rasional merupakan hal yang tidak mudah.

Tujuan. Memperbaiki kuantitas dan kualitas penggunaan antibiotik pada pasien yang dirawat dengan demam, serta mengevaluasi dampak terhadap morbiditas dan mortalitas. Metoda. Penelitian prospektif intervensi di bangsal anak RS Dr Kariadi, Juli 2003 Desember 2004, dibagi menjadi 4 periode yaitu periode awal, penyusunan pedoman, pelatihan, dan umpan balik. Pada periode awal dilakukan pengambilan data dasar. Pada periode penyusunan pedoman dilakukan konsensus untuk menyusun pedoman penggunaan antibiotik pada anak dengan demam. Periode pelatihan adalah sosialisasi dan pelatihan kepada dokter. Pada periode pascapelatihan dilakukan umpan balik terhadap peserta pelatihan. Subyek penelitian adalah semua pasien usia $>1$ bulan yang dirawat dengan demam $>38^{\circ} \mathrm{C}$ (rektal) dalam 24 jam pertama perawatan, kecuali yang diketahui menderita HIV/AIDS atau neutropeni karena kemoterapi. Data penggunaan antibiotik diambil dari catatan medik, diamati selama 6 hari pertama perawatan. Data morbiditas dan mortalitas diamati sampai pasien keluar dari rumah sakit. Uji statistik menggunakan $\mathrm{X}^{2}$ dan Anova. Hasil. Terdapat penurunan kuantitas penggunaan antibiotik dan peningkatan kualitas penggunaan antibiotik secara bermakna $(\mathrm{p}=0.000$ dan $\mathrm{p}=0,000)$. Penurunan kuantitas antibiotiok terutama disebabkan pengurangan penggunaan antibiotik yang tidak diperlukan. Tidak terdapat perbedaan lama rawat dan lama demam ( $\mathrm{p}=0.96$ dan $\mathrm{p}=0.32$ ) dan tidak terdapat perbedaan kematian selama periode pengamatan.

Kesimpulan. Dengan pedoman yang baik, penggunaan jumlah antibiotik dapat diturunkan tanpa meningkatkan risiko morbiditas dan mortalitas.
\end{abstract}

Kata kunci: resistensi antibiotik, pedoman dan pelatihan

\footnotetext{
Alamat korespondensi:

Dr. M.M.Hapsari, SpA * Subbagian Infeksi dan Penyakit Tropis, Bagian Ilmu Kesehatan Anak FK UNDIP-RS Dr Kariadi, Semarang. **Bagian Mikrobiologi FK UNDIP-RS Dr Kariadi, Semarang. ***Nijmegen University Center of Infectious Disease and International Health Department of Internal Medicine. ${ }^{* * * *}$ Department of Infectious Disease, Leiden University Medical Centre ${ }^{* * * * *}$ Sub Bagian Infeksi dan Penyakit Tropis Bagian Penyakit Dalam FK UNAIR-RS Dr Soetomo, Surabaya.
}

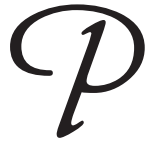

enemuan antibiotik dan penggunaannya secara luas dalam bidang kesehatan sejak tahun 1943 telah memberikan banyak manfaat yaitu penurunan tajam angka kesakitan dan kematian akibat infeksi. ${ }^{1,2}$ Penggunaan antibiotik yang kurang bijaksana dan masalah resistensi antibiotik khususnya pada pasien bayi dan anak telah lama menjadi perhatian khusus. Dua hal yang melatar- 
belakangi penggunaan antibiotik berlebihan pada anak adalah kekhawatiran tidak dapat membedakan infeksi bakterial dari sebab demam lainnya dan kekhawatiran infeksi bakterial dapat memburuk dengan cepat akibat sistem imun yang belum sempurna. ${ }^{3-5}$

Untuk mengatasi kedua hal tersebut perlu disusun pedoman/panduan untuk membedakan suatu penyakit infeksi bakterial (antibiotik akan bermanfaat) dari penyebab penyakit lainnya (antibiotik tidak bermanfaat), serta untuk mengenali dan membedakan infeksi bakterial berat (perlu segera diberi antibiotik emprik) dari infeksi yang tidak berat (antibiotik dapat ditunda sampai diperoleh bukti bakteri sebagai penyebab infeksi). Demam pada anak seringkali tidak disertai fokus infeksi yang jelas sehingga dokter sulit memperkirakan apakah mikroba penyebabnya adalah bakteri atau bukan. Penyusunan dan penyebarluasan pedoman pemberian antibiotik pada anak dengan demam, khususnya demam tanpa fokus yang jelas, merupakan hal yang sangat penting untuk mengurangi penggunaan antibiotik yang tidak tepat. Pedoman terapi antibiotik umumnya ditujukan pada kasus yang telah jelas diagnosis dan jelas fokus infeksi, padahal sebagian besar pasien demam datang tanpa fokus infeksi bakterial yang jelas. Dibutuhkan waktu beberapa hari untuk mengidentifikasi ada tidaknya fokus infeksi bakteri dan menegakkan diagnosis. Secara internasional telah tersedia beberapa pedoman pemberian antibiotik pada anak dengan demam, seperti kriteria Rochester, dan kriteria Yale. ${ }^{6,7}$ Tetapi situasi di Indonesia, seperti keterbatasan sarana diagnostik, keterbatasan cakupan asuransi kesehatan serta kekhawatiran akan terjadi infeksi bakterial yang berat, dokter pada umumnya memilih untuk segera memberikan antibiotik segera setelah mendapatkan pasien dengan demam (data belum dipublikasikan). Akibatnya frekuensi pemakaian antibiotik menjadi sangat tinggi dan banyak diantaranya yang tidak diperlukan (diberikan tanpa indikasi). Dampak lebih lanjut adalah masalah resistensi bakteri akan semakin berat, dan biaya perawatan kesehatan menjadi semakin tinggi. Penelitian pendahuluan Antimicrobial Resistance in Indonesia, Prevalence and Prevention (AMRIN) Study pada tahun 2001 di bangsal rawat inap anak RS Dr. Kariadi Semarang dan RS Dr. Soetomo Surabaya, mendapatkan bahwa tingkat konsumsi antibiotik sangat tinggi (lebih dari $90 \%$ pasien yang dirawat di rumah sakit tersebut mendapatkan antibiotik), 46- 54\% di antaranya sebenarnya tidak ada indikasi pemberian antibiotik.
Berdasarkan hal tersebut di atas, dipandang perlu untuk menyusun pedoman pemberian antibiotik pada pasien dengan demam, khususnya bila fokus infeksi bakterial tidak ditemukan (diagnosis pasti belum ditegakkan). Pedoman tersebut di RS Dr. Kariadi telah disusun berdasarkan telah pustaka dan konsensus dokter spesialis anak. Dengan pedoman tersebut diharapkan pemakaian antibiotik secara keseluruhan akan berkurang, dan kualitas penggunaan antibiotik meningkat sehingga keluaran pasien tetap optimal dan baik. Penelitian ini bertujuan untuk mengevaluasi dampak penggunaan pedoman tersebut terhadap kuantitas dan kualitas penggunaan antibiotik, serta terhadap morbiditas dan mortalitas pasien yang dirawat dengan demam.

\section{Metoda Penelitian}

Penelitian ini merupakan studi prospektif intervensi yang dilakukan di bangsal anak RS Dr Kariadi Semarang dari bulan 17 Juli 2003 sampai dengan 31 Desember 2004, dibagi menjadi 4 periode yaitu periode I (awal/data dasar), II penyusunan pedoman, III Pelatihan, dan IV Umpan balik. Pada periode I (17 Juli-31 Desember 2003 dan 1 Maret-2 Mei 2004) dilakukan pengambilan data dasar (awal). Pada periode II atau periode Penyusunan pedoman (3 Mei -13 Mei 2004) dilakukan penyusunan pedoman penggunaan antibiotik pada anak dengan demam oleh para dokter spesialis anak berdasarkan telaah kepustakaan dan diskusi untuk mencapai konsensus. Periode III atau periode pelatihan (14 Mei-22 Juli 2004) adalah sosialisasi dan pelatihan kepada dokter yang dilaksanakan dalam 2 tahap. Pada periode IV atau periode Umpan balik (23 Juli-31 Desember 2004 ) dilakukan umpan balik terhadap peserta pelatihan sebanyak dua kali dengan selang waktu satu bulan..

Subyek penelitian adalah semua pasien usia di atas 1 bulan yang masuk dirawat di bangsal anak dengan demam lebih dari $38^{\circ} \mathrm{C}$ (temperatur rektal) saat datang atau dalam 24 jam pertama perawatan, kecuali yang diketahui menderita HIV/AIDS, keganasan dan demam neutropeni. Data awal kuantitas, kualitas, morbiditas dan mortalitas pasien dengan demam dicatat (periode awal). Perlakuan yang diamati dampaknya adalah penyusunan pedoman penggunaan antibiotik (periode penyusunan), pelatihan dokter (periode pelatihan) serta pemberian umpan balik (periode umpan balik). Pedoman penggunaan antibiotik 
yang baru ini dalam bentuk algoritme yang memberikan petunjuk pasien yang membutuhkan dan tidak membutuhkan antibiotik pada saat mulai dirawat yang biasanya informasi klinik dan laboratorium belum lengkap. Untuk membedakan kedua kelompok pasien ini dasar pertimbangannya meliputi ada tidaknya SIRS (systemic inflammatory respon syndrome), umur, dan ada tidaknya fokus infeksi bakteri. (Gambar 1)

Pedoman penggunaan antibiotik pada anak dengan demam pada dasarnya untuk membedakan kasus yang membutuhkan antibiotik atau tidak. Kelompok pasien yang mendapatkan antibiotik bila masuk salah satu kriteia sebagai berikut,

1. Terdapat tanda-tanda sindrom respon inflamasi sistemik (SRIS), kecuali apabila SRIS tersebut diduga disebabkan oleh infeksi virus.

2. Terdapat fokus infeksi bakterial, misalnya infeksi saluran kemih, infeksi kulit bernanah, pneumonia, meningitis.

3. Umur kurang dari 3 bulan (tanpa memandang ada/ tidak adanya SRIS ataupun fokus infeksi bakterial)

Apabila pasien tidak memenuhi minimal satu kriteria di atas, maka pasien tidak diberikan antibiotik. Meskipun demikian, upaya diagnostik untuk mengidentifikasi adanya infeksi bakterial tetap harus dilakukan, misalnya kultur, dan pemantauan harian berkembangnya tandatanda yang sesuai dengan kriteria di atas yang semula

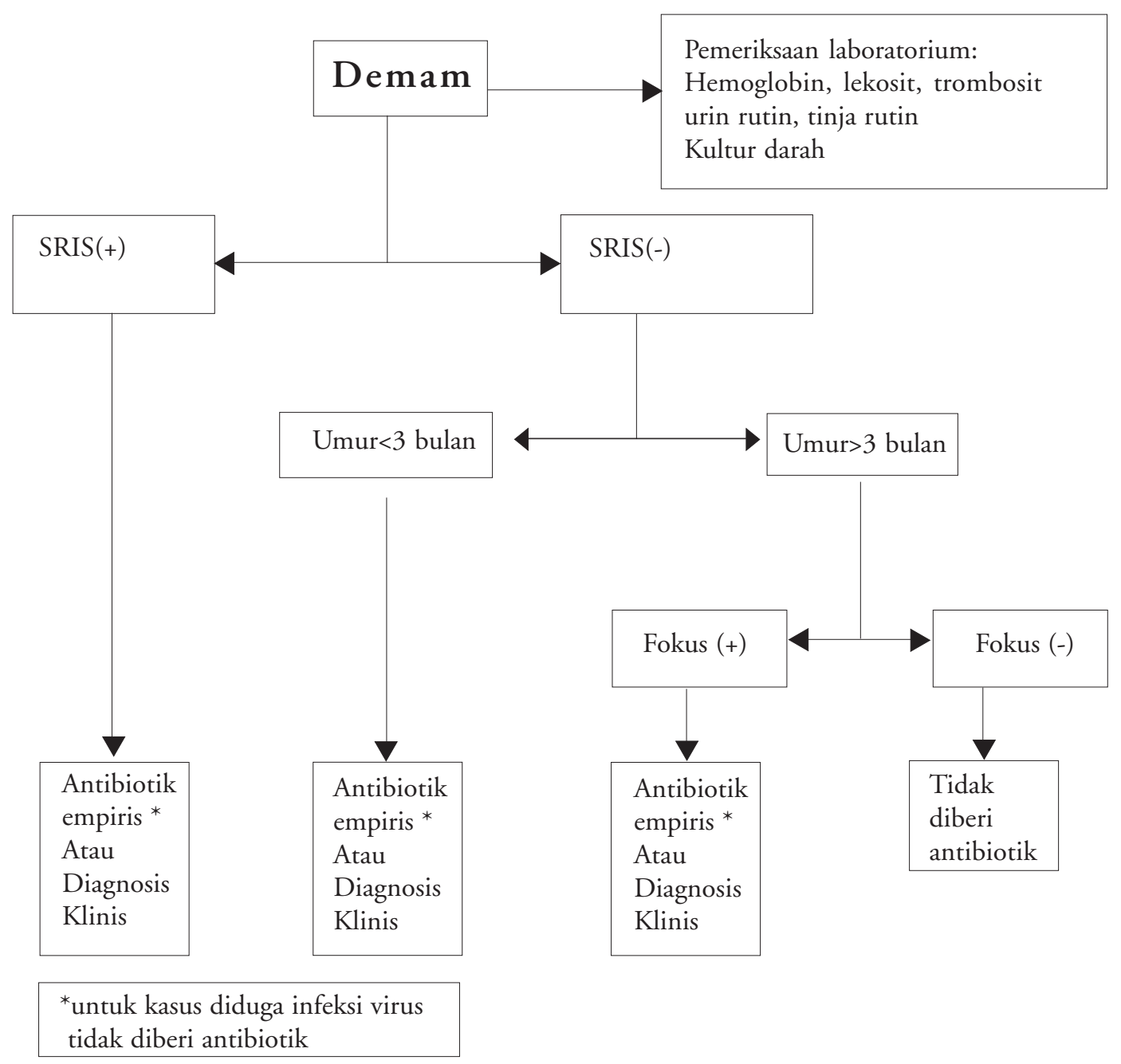

Gambar 1. Algoritme Pedoman Penggunaan Antibiotik pada anak dengan demam 
tidak didapatkan. Pada ketiga periode diatas diamati pula tentang kuantitas dan kualitas antibiotik serta morbiditas dan mortalitas pasien.

Kuantitas antibiotik yang digunakan dihitung sebagai DDD (defined daily dose), yaitu dosis rata rata harian untuk obat (antibiotik) tertentu per 100 hari pasien menurut WHO tahun $2000 .{ }^{8}$ Data penggunaan antibiotik diambil dari catatan medik pasien dan diamati selama 6 hari pertama perawatan.

Kualitas penggunaan antibiotik adalah proporsi dan rerata skor yang diperoleh dari resep pasien demam yang dibuat oleh subyek penelitian dalam tingkat ketepatan peresepan antibiotik, yang diambil datanya dari catatan medis, dengan skala interval, menurut Kunin dkk dikutip Gyssens tahun 1992. ${ }^{9}$ Nilai rerata diberi bobot sebagai berikut,

$0=$ Peresepan antibiotik tanpa indikasi

$1=$ Peresepan antibiotik yang tepat indikasi, tetapi tidak tepat dosis/ interval/rute pemberian

$2=$ Peresepan antibiotik yang tepat indikasi, tepat dalam dosis/interval/rute pemberian, tetapi tidak tepat dalam lama pemberian

$3=$ Peresepan antibiotik yang tepat indikasinya, dosis/ interval/rute, serta lama pemberian, tetapi tidak tepat jenisnya (tidak sesuai dengan pola kuman dan kepekaan setempat/tidak sesuai dengan pedoman dalam pelatihan)

$4=$ Peresepan antibiotik yang tepat indikasinya, dosis/ interval/rute, serta lama pemberian jenisnya, atau tidak diresepkan antibiotik pada keadaan yang memang tidak ada indikasi antibiotik.

Kualitas penggunaan antibiotik ini dinilai oleh dua orang observer (spesialis anak dan spesialis mikrobiologi klinik) secara independen. Kesesuaian diantara 2 observer diukur dengan Kappa. Morbiditas diukur berdasarkan lama rawat dan lama demam turun (time of defervescence) yaitu waktu yang dibutuhkan untuk kembali ke suhu normal. Sedangkan untuk mortalitas diukur dari hasil akhir pasien. Data morbiditas serta mortalitas diambil dari rekam medik, diamati sampai pasien keluar dari rumah sakit. Uji statistik parametrik menggunakan Anova, dan non parametrik dengan $\mathrm{X}^{2}$.

\section{Hasil Penelitian}

Selama penelitian telah tercatat jumlah pasien yang dirawat 1438 anak, kasus dengan demam sebanyak 504
(35\% dari total pasien), dengan 491 orang di antaranya memenuhi kriteria inklusi.

\section{a. Karakteristik subyek}

Jumlah antibiotik yang diberikan pada pasien anak selain dipengaruhi oleh umur juga dipengaruhi oleh berat badan pasien. Adapun distribusi pasien menurut umur dan berat badan serta alasan dirawat ditampilkan pada Tabel 1. Tidak terdapat perbedaan bermakna pada distribusi umur dan berat badan subyek pada masing-masing periode.

Sebaran diagnosis awal selama penelitian didapatkan 10 besar penyakit $(71,8 \%)$ sebagai berikut, infeksi saluran pernafasan akut $14 \%$, infeksi dengue $13 \%$, infeksi virus $9 \%$, gastroenteritis $8 \%$, dan pneumonia serta kejang 7\%, (campak/rubela/cacar air) didapatkan 5,8\% demam tifoid 5\%, serta infeksi saluran kemih 2\%, meningitis $1 \%$. Morbiditas lainnya hanya sedikit prosentasenya misalnya infeksi kulit serta tetanus, difteria, sepsis, keganasan, dan hepatitis,malaria. Perbedaan distribusi diagnosis ini pada keempat periode berbeda bermakna $(\mathrm{p}=0.001)$. Selanjutnya peneliti mengelompokkan sebaran pasien berdasarkan ada tidaknya indikasi pemberian antibiotik (menurut pedoman yang baru), sebagai mana pada Tabel 2. Hasil uji statistik menunjukkan sebaran indikasi pemberian antibiotik pada keempat periode tidak berbeda bermakna.

\section{b. Kuantitas dan Kualitas Penggunaan antibiotik}

Rerata kuantitas/jumlah antibiotik tiap hari yang dihitung berdasarkan pemakaian obat per 100 pasien hari (defined daily dose/DDD) menunjukkan penurunan bermakna pada semua kasus $(\mathrm{p}=0.010)$ dan pada kasus tanpa indikasi antibiotik $(\mathrm{p}=0.000)$ sebagaimana tercantum pada Tabel 3, yang mempunyai arti bahwa setelah dilakukan pelatihan nampak penggunaan antibiotik pada pasien anak dengan demam mengalami penurunan. Ini berarti algoritme yang digunakan dalam pedoman itu cukup efektif untuk menekan penggunaan antibiotik pada anak dengan demam.

Untuk menilai kualitas penggunaan antibiotik setiap periode, dilakukan review terhadap pe- 
Sari Pediatri, Vol. 8, No. 1, Juni 2006

Tabel 1. Karakteristik Subyek

\begin{tabular}{|c|c|c|c|c|c|c|}
\hline Jenis Kelamin & $\begin{array}{l}\text { P.Awal } \\
(\%)\end{array}$ & $\begin{array}{l}\text { P.Penyusunan } \\
\text { Pedoman (\%) }\end{array}$ & $\begin{array}{l}\text { P.Pelatihan } \\
(\%)\end{array}$ & $\begin{array}{l}\text { P.Umpan } \\
\text { Balik (\%) }\end{array}$ & $\begin{array}{l}\text { Total } \\
(\%)\end{array}$ & $p^{*}$ \\
\hline Laki & $128(44)$ & $6(55)$ & $32(49)$ & $52(42)$ & $218(45)$ & 0.85 \\
\hline Perempuan & $162(56)$ & $5(45)$ & $34(51)$ & $72(58)$ & $273(55)$ & \\
\hline \multicolumn{7}{|l|}{ Umur } \\
\hline$<3$ bulan & $16(5)$ & $1(9)$ & $4(6)$ & $1(1)$ & $22(5)$ & 0.61 \\
\hline 3 bln-3 thn & $168(58)$ & $9(82)$ & $41(62)$ & $83(67)$ & $301(61)$ & \\
\hline $3-5$ tahun & $33(12)$ & $1(9)$ & $7(11)$ & $15(12)$ & $56(12)$ & \\
\hline 5-10 tahun & $52(18)$ & $0(0)$ & 12(19) & $14(11)$ & $78(15)$ & \\
\hline$>10$ tahun & $21(7)$ & $0(0)$ & $2(3)$ & $11(9)$ & $34(7)$ & \\
\hline \multicolumn{7}{|l|}{ Berat Badan (kg) } \\
\hline$<10$ & $146(50)$ & $7(64)$ & $36(55)$ & $67(54)$ & $256(52)$ & 0.27 \\
\hline $10.1-20$ & $92(32)$ & $4(36)$ & $24(37)$ & $40(32)$ & $160(33)$ & \\
\hline $20.1-30$ & $35(12)$ & $0(0)$ & $4(6)$ & $10(8)$ & $49(10)$ & \\
\hline$>30$ & $16(6)$ & $0(0)$ & $2(3)$ & $7(6)$ & $25(5)$ & \\
\hline \multicolumn{7}{|l|}{ Diagnosis } \\
\hline $\begin{array}{l}\text { Tak ada diagnosa } \\
\text { definitif }\end{array}$ & $40(14)$ & $2(18)$ & $7(11)$ & $51(42)$ & $100(20)$ & 0.01 \\
\hline Demam tifoid & $15(5)$ & $0(0)$ & $4(6)$ & $5(4)$ & $24(5)$ & \\
\hline Pneumonia & $17(6)$ & $0(0)$ & $12(18)$ & $4(3)$ & $33(7)$ & \\
\hline Gastroen teritis & $22(8)$ & $1(9)$ & $3(5)$ & $12(10)$ & $38(8)$ & \\
\hline Meningitis & $3(1)$ & $0(.0)$ & 1(1) & $3(2)$ & $7(1)$ & \\
\hline Infeksi kulit & $1(0.3)$ & $0(0)$ & $0(0)$ & $0(0)$ & $1(0.2)$ & \\
\hline Infeksi sal kemih & $5(2)$ & $0(0)$ & 1(1) & $2(1)$ & $8(2)$ & \\
\hline Infeksi dengue & $54(19)$ & $0(0)$ & $6(9)$ & $4(3)$ & $64(13)$ & \\
\hline Morbili & $9(3)$ & $3(27)$ & $7(11)$ & $8(6)$ & $27(5.8)$ & \\
\hline ISPA & $44(15)$ & $3(27)$. & $9(14)$ & $11(9)$ & $67(14)$ & \\
\hline $\begin{array}{l}\text { Infeksi virus } \\
\text { (Infuenza, } \\
\text { Bronkiolitis) }\end{array}$ & $26(9)$ & $1(9)$. & $3(5)$ & $15(12)$ & $45(9)$ & \\
\hline $\begin{array}{l}\text { Difteria, } \\
\text { Malaria, tetanus, } \\
\text { Sepsis }\end{array}$ & $7(2.7)$ & $0(0)$ & $4(6)$ & $4(3)$ & $15(2)$ & \\
\hline Kejang & $20(15)$ & $1(9)$ & $8(13)$ & $6(5)$ & $35(7)$ & \\
\hline
\end{tabular}

- Uji beda dengan $\mathrm{X}^{2}$

Tabel 2. Distribusi ada dan tidaknya indikasi antibiotik per periode

\begin{tabular}{|c|c|c|c|c|c|c|}
\hline \multirow{2}{*}{$\begin{array}{l}\text { Indikasi } \\
\text { antibiotik }\end{array}$} & \multicolumn{4}{|c|}{ Periode } & \multirow{2}{*}{$\begin{array}{l}\text { Total } \\
(\%)\end{array}$} & \multirow[t]{2}{*}{$P^{*}$} \\
\hline & Awal (\%) & $\begin{array}{l}\text { Penyusunan } \\
\text { Pedoman (\%) }\end{array}$ & $\begin{array}{l}\text { Pelatihan } \\
(\%)\end{array}$ & $\begin{array}{l}\text { Umpan } \\
\text { Balik (\%) }\end{array}$ & & \\
\hline Ada indikasi & & $7(36)$ & $32(58)$ & $65(61)$ & $250(56)$ & 0,20 \\
\hline $\begin{array}{l}\text { Tidak ada } \\
\text { indikasi }\end{array}$ & $\begin{array}{l}146(54) \\
127(46)\end{array}$ & $4(64)$ & $58(62)$ & $61(39)$ & $196(44)$ & \\
\hline
\end{tabular}

- Uji beda dengan $\mathrm{X}^{2}$ 
resepan yang ditulis sejak 1 Oktober $2003-31$ Desember 2004. Didapatkan 1237 resep dengan hasil evaluasi tertera pada Tabel 4. Dari tabel tersebut, didapatkan perbedaan bermakna pada kualitas penggunaan antibiotik, dengan menurunnya proporsi antibiotik yang diresepkan tanpa indikasi dan meningkatnya proporsi antibiotik yang diresepkan secara tepat (tepat indikasi dan pemberian). Berarti bahwa algoritme pedoman penggunaan antibiotik yang ditambah dengan pelatihan dan umpan balik dapat meningkatkan kualitas penggunaan antibiotik .

\section{Morbiditas dan Mortalitas}

Tabel 5 menunjukkan tidak terdapat perbedaan perbandingan morbiditas pasien pada keempat periode. Sedangkan morbiditas dinilai berdasarkan rerata lama rawat dan rerata lama demam turun. Mortalitas dinilai berdasarkan prognosis pasien (sembuh/perbaikan, memburuk, atau meninggal), menunjukkan prognosis pasien pada kelompok kasus dengan indikasi dan tanpa indikasi antibiotik pada keempat periode tidak berbeda bermakna. Dari Tabel 5 tersebut dapat disimpulkan bahwa dengan penggunaan antibiotik yang lebih rendah, morbiditas dan mortalitas tidak menjadi lebih buruk dibandingkan ketika frekuensi penggunaan antibiotik lebih tinggi.

Selama kurun waktu penelitian terdapat 9 pasien meninggal, disebabkan berbagai hal antara lain sepsis $(44 \%)$, bronkopneumonia (22\%), keganasan (22\%) dan ensefalitis (12\%). Delapan kasus meninggal adalah kasus dengan indikasi antibiotik dan satu kasus meninggal berawal dari kelompok tanpa indikasi antibiotik. Kasus tersebut terjadi pada periode awal, dan data menunjukkan

Tabel 3. DDD perhari pada semua kasus, kasus pada indikasi antibiotik dan tanpa indikasi antibiotik

\begin{tabular}{lcllll}
\hline $\begin{array}{l}\text { Indikasi pemberian } \\
\text { antibiotik }\end{array}$ & P. awal & $\begin{array}{l}\text { P.Penyusunan } \\
\text { Pedoman }\end{array}$ & P. Pelatihan & P. Umpan Balik & $p^{*}$ \\
\hline $\begin{array}{l}\text { Semua kasus } \\
\text { Kasus dengan }\end{array}$ & 0.48 & 0.46 & 0.40 & 0.38 & 0.010 \\
$\begin{array}{l}\text { indikasi antibiotik } \\
\begin{array}{l}\text { Kasus tanpa indikasi } \\
\text { antibiotik }\end{array}\end{array}$ & 0.45 & 0.43 & 0.46 & 0.49 & 0.800 \\
\hline
\end{tabular}

- Uji beda dengan Anova

Tabel 4. Kualitas penggunaan antibiotik pada masing-masing periode

\begin{tabular}{|c|c|c|c|c|c|c|}
\hline \multirow[b]{2}{*}{$\begin{array}{l}\text { Kualitas } \\
\text { antibiotik }\end{array}$} & \multirow[b]{2}{*}{ awal (\%) } & \multirow[b]{2}{*}{$\begin{array}{l}\text { Penyusunan } \\
\text { Pedoman (\%) }\end{array}$} & \multicolumn{2}{|c|}{ Periode } & \multirow[b]{2}{*}{ Total } & \multirow[b]{2}{*}{$p^{*}$} \\
\hline & & & Pelatihan (\%) & Umpan Balik (\%) & & \\
\hline $\begin{array}{l}\text { Antibiotik tanpa } \\
\text { indikasi }\end{array}$ & $232(43)$ & $6(22)$ & $89(27)$ & $78(17)$ & 405 & 0.000 \\
\hline $\begin{array}{l}\text { Antibiotik tepat } \\
\text { indikasi tetapi } \\
\text { tidak tepat dalam } \\
\text { pemberian }\end{array}$ & $111(20)$ & $8(30)$ & $69(20)$ & $95(20)$ & 283 & \\
\hline \multirow[t]{2}{*}{$\begin{array}{l}\text { Antibiotik tepat } \\
\text { indikasi dan } \\
\text { pemberian }\end{array}$} & $202(37)$ & $13(48)$ & $173(53)$ & $295(63)$ & 683 & \\
\hline & 533 & 26 & 298 & 380 & 1237 & \\
\hline
\end{tabular}

Uji beda dengan Anova 
Tabel 5. Morbiditas,mortalitas dan luaran pasien

\begin{tabular}{|c|c|c|c|c|c|}
\hline & \multicolumn{4}{|c|}{ Periode } & \multirow[t]{2}{*}{$\mathrm{p}^{*}$} \\
\hline & $\begin{array}{l}\text { Awal } \\
(\%)\end{array}$ & $\begin{array}{l}\text { Penyusunan } \\
\text { Pedoman (\%) }\end{array}$ & $\begin{array}{l}\text { Pelatihan } \\
(\%)\end{array}$ & $\begin{array}{l}\text { Umpan } \\
\text { Balik (\%) }\end{array}$ & \\
\hline \multicolumn{6}{|l|}{ Rerata lama rawat (hari) } \\
\hline $\begin{array}{l}\text { a. Kasus tanpa } \\
\text { indikasi antibiotik }\end{array}$ & 5,5 & 4,8 & 4,6 & 6,0 & 0,32 \\
\hline $\begin{array}{l}\text { b. Kasus dengan } \\
\text { indikasi antibiotik }\end{array}$ & 6,6 & 4,5 & 9,1 & 7,3 & 0,21 \\
\hline \multicolumn{6}{|c|}{ Rerata lama demam turun (hari) } \\
\hline $\begin{array}{l}\text { 1. Kasus tanpa } \\
\text { indikasi antibiotik }\end{array}$ & 2,2 & 1,9 & 2,0 & 2,2 & 0,96 \\
\hline $\begin{array}{l}\text { 2. Kasus dengan } \\
\text { indikasi antibiotik }\end{array}$ & 3,0 & 2,2 & 4,4 & 3,2 & 0,28 \\
\hline \multicolumn{6}{|l|}{$\begin{array}{l}\text { 1. Kelompok tanpa } \\
\text { indikasi antibiotik }\end{array}$} \\
\hline Sembuh & $150(98)$ & $5(100)$ & $26(96)$ & $49(98)$ & 0,98 \\
\hline Perburukan & $1(1)$ & $0(0)$ & $0(0)$ & $0(0)$ & \\
\hline Meninggal & $1(1)$ & $0(0)$ & $0(0)$ & $0(0)$ & \\
\hline \multicolumn{6}{|c|}{$\begin{array}{l}\text { 2. Kelompok dengan } \\
\text { indikasi antibiotik (\%) }\end{array}$} \\
\hline Sembuh & $131(96)$ & $6(100)$ & $38(95)$ & $69(95)$ & 0,88 \\
\hline Perburukan & $3(2)$ & $0(0)$ & $0(0)$ & $1(1)$ & \\
\hline Meninggal & $3(2)$ & $0(0)$ & $2(5)$ & $3(4)$ & \\
\hline
\end{tabular}

- Uji beda dengan Anova

bahwa pasien tetap diberi antibiotik walaupun termasuk kasus tanpa indikasi antibiotik. Tidak terdapat kematian pada kelompok tanpa indikasi antibiotik setelah periode penyusunan pedoman.

\section{Pembahasan}

Demam adalah keluhan pada anak yang paling sering dijumpai, sekitar $10-31 \%$ dari semua keluhan yang diketemukan pada instalasi gawat darurat atau dalam praktek sehari-hari. ${ }^{9}$

Pada penelitian ini didapatkan presentase terbanyak pasien demam berumur 3 bulan-3 tahun (65\%). Sebaran proporsi pasien menurut umur dan berat badan, dua faktor yang menentukan banyaknya penggunaan antibiotik, pada keempat periode tidak berbeda bermakna. Sebaran diagnosis penyakit berbeda bermakna, tetapi sebaran kategori kasus (membutuhkan atau tidak membutuhkan antibiotik) pada keempat periode tidak berbeda bermakna. Dengan demikian bias dalam penghitungan kuantitas dan kualitas penggunaan antibiotik dapat direduksi.

Setelah diberlakukan pedoman penggunaan antibiotik pada anak dengan demam yang merupakan hasil konsensus bersama, secara umum terjadi pengurangan rerata $\mathrm{DDD} /$ hari dalam 6 hari pertama. Pengurangan jumlah gram antibiotik per 100 pasien hari yang digunakan pada kasus tanpa indikasi antibiotik turun namun tidak bermakna pada periode konsensus, dan mulai turun secara bermakna pada periode pelatihan. Pada pasca pelatihan, DDD juga turun lebih rendah lagi, tetapi secara stasistik tidak bermakna. Ini berarti bahwa dampak pelatihan dalam waktu pendek dapat dipertahankan dengan adanya pemberian penyegaran dan umpan balik. Sedangkan pada kasus dengan indikasi antibiotik DDD justru meningkat tetapi tidak bermakna. Hal ini disebabkan banyaknya infeksi bakterial yang berat seperti 
meningitis, pnemonia berat, dan sepsis berat yang membutuhkan antibiotik kombinasi pada periode pelatihan dan periode pasca pelatihan.

Meskipun penurunan DDD pada kasus tanpa indikasi antibiotik tampak menggembirakan, hasil tersebut belum optimal, karena DDD pada kasus tanpa indikasi antibiotik seharusnya adalah 0 (nol) sedangkan pada penelitian ini DDD masih 0.22. Analisis lebih lanjut mengenai sebab ketidakpatuhan dokter sehingga masih meresepkan antibiotik pada keadaan yang tidak membutuhkan suatu antibiotik akan dibahas pada bagian II dari laporan penelitian ini.

Kualitas penggunaan antibiotik membaik terutama pada kategori penyakit yang tidak ada indikasi antibiotik, yaitu berkurangnya pemberian antibiotik tanpa indikasi. Jadi penurunan DDD disebabkan berkurangnya pemakaian antibiotik tanpa indikasi. Temuan ini menunjukkan perbaikan dalam penentuan keputusan untuk tidak memberikan antibiotik pada kasus yang memang tidak ada indikasi antibiotik.

Pada hari-hari pertama perawatan, seringkali informasi diagnostik belum lengkap. Dokter seringkali segera memutuskan untuk memberi antibiotik karena khawatir tidak dapat membedakan kasus infeksi bakteri yang benar-benar membutuhkan antibiotik atau kasus yang potensial mengalami infeksi berat. Panduan terapi antibiotik yang tersedia pada umumnya mengatur penggunaan antibiotik pada penyakit yang sudah jelas diagnosisnya, dan tidak mengatur penggunaan antibiotik pada kasus-kasus demam yang belum jelas diagnosisnya. Padahal sebagian besar pasien belum jelas diagnosisnya pada hari-hari pertama perawatan. Panduan baru yang disusun berdasarkan konsensus di Bagian Anak Fakultas Kedokteran Universitas Diponegoro/RS Dr. Kariadi di atas dapat diterapkan pada kasus-kasus demam yang diagnosisnya belum jelas, yaitu antibiotik diberikan bila terdapat satu dari 3 kriteria yaitu terdapat tanda SRIS, umur kurang dari 3 bulan, serta dijumpai fokus infeksi bakterial. Di luar ketiga kriteria tersebut seyogyanya penderita tidak diberi antibiotik; namun upaya diagnostik untuk mencari adanya infeksi bakterial seperti biakan dan monitoring setiap hari harus tetap dilakukan. Apabila ditemukan biakan positif, atau timbul tanda fokus infeksi bakterial atau tanda SRIS yang semula belum nampak, antibiotik segera diberikan sesuai hasil biakan, atau sesuai dengan pola empiriknya.

Dari Tabel 5, tampak bahwa dengan pengurangan penggunaan antibiotik yang didasarkan pada panduan baru tersebut, morbiditas dan mortalitas tidak berbeda bermakna. Hal ini memiliki dua arti penting, yang pertama adalah efisiensi biaya perawatan pasien dengan menghindari penggunaan antibiotik yang tidak perlu dan mengurangi masalah resistensi. Kedua, panduan tersebut secara umum masih memungkinkan pengenalan kasus yang potensial menjadi berat sehingga boleh diberikan antibiotik, sehingga tidak terjadi perburukan prognosis yang diakibatkan tidak atau terlambat diberikannya antibiotik.

Meskipun demikian terdapat dua catatan yang perlu disampaikan. Pertama, dijumpai satu kasus pasien pada periode awal yang apabila dinilai dengan panduan baru tersebut, tergolong kasus yang tidak membutuhkan antibiotik; di kemudian hari terbukti menderita penyakit keganasan dan sepsis. Saat pasien mulai dirawat sebenarnya pasien menunjukkan penampilan sakit berat (toksik), walaupun pada pasien ini tidak ada tanda-tanda SRIS. Dengan demikian perlu dipikirkan untuk menambahkan kriteria penampilan anak (clinical appearancelclinical presentation) sebagai salah satu kriteria pemberian antibiotik. Pasien yang dikelompokkan dengan menggunakan kriteria tambahan ini kemudian dianalisis dan dibandingkan dengan bila dikelompokkan menurut pedoman yang dipakai. Beberapa senter pendidikan dan pelayanan kesehatan anak memang menggunakan kriteria tersebut sebagai salah satu indikator perlu tidaknya diberikan antibiotik, misalnya Skala Observasi Yale (Yale score) yang telah dipakai cukup luas secara internasional. ${ }^{6,7}$ Penelitian ini memilih menggunakan kriteria SRIS dari pada Skor Yale karena dalam forum konsensus Skor Yale tidak disetujui dan dianggap terlalu rumit.

Catatan kedua adalah walaupun telah terjadi penurunan kuantitas penggunaan antibiotik (DDD) secara bermakna, belum sepenuhnya dapat dikatakan bahwa panduan tersebut merupakan "penyaring" optimal untuk mereduksi penggunaan antibiotik yang tidak perlu. Tidak tertutup kemungkinan bahwa panduan masih terlalu "longgar", sehingga kasus yang benar-benar tidak membutuhkan antibiotik, dengan panduan tersebut masih tergolong pada kelompok kasus yang membutuhkan antibiotik. Dalam hal ini peneliti kesulitan mendapatkan pembanding, karena belum ada penelitian yang mengukur DDD antibiotik pada anak. Nilai DDD yang tersedia secara internasional adalah ukuran DDD antibiotik untuk orang dewasa. ${ }^{10}$ Penelitian yang dipublikasi mengenai ketepatan penggunaan kriteria misalnya skor Yale dan 
menilai keluaran pasien, bukan mempergunakan DDD.

\section{Kesimpulan}

Penerapan konsensus pedoman dan tata laksana penggunaan antibiotik pasien anak dengan demam disertai intervensi pelatihan dapat mengurangi penggunaan antibiotik yang berlebihan dan meningkatkan rasionalitas, tanpa meningkatkan risiko morbiditas dan mortalitas. Meskipun demikian, masih perlu dilakukan penelitian lanjutan untuk dapat lebih memastikan bahwa pedoman tersebut memiliki sensitifitas dan spesifisitas yang baik dalam membedakan pasien yang membutuhkan antibiotik dan yang tidak, khususnya untuk diterapkan di negara berkembang yang memiliki keterbatasan sarana diagnostik.

\section{Daftar Pustaka}

1. WHO. WHO global strategy for containment of antimicrobial resistance. Geneva: Department of Communicable Disease Surveillance and Response; 2001.

2. Blondeau J. Appropriate antibiotic use: past lessons provide future direction. Dalam: Low D, Penyunting. In- ternational Congress and Symposium; 2001; London: Royal Society of Medicine Press; 2001. h. 1-9.

3. Walduogel F. New resistance in Staphylococcus aureus. NEJM 1998; 340:556- 7.

4. Finkelstein JA DR, Dowell SF, Metlay JP, Soumerai SB, Rifas-Shiman SL, Higham M. Reducing antibiotic use in children: a randomized trial in 12 practices. Pediatrics 2001; 108:1-8.

5. Sharon Y. Antibiotic resistance. Rogers media 1999; 22:25-31.

6. Kramer M. The young febrile child: evidence-based diagnostic and therapeutic strategies. Emerg Med Pract 2000; 2:1-24.

7. Pomeranz J, Busey S, Sabnis SS, Behrman R, Kliegman R. Pediatric decision-making strategies. To accompany Nelson textbook of pediatrics, Edisi 16. Toronto: WB Saunders; 2002.

8. WHO. Collaborating centre for drug statistic methodology. Guidelines for ATC classification and DDD aasignment. Oslo, Norway; 2000.

9. Gyssens IC, Van den Broek PJ, Kullberg BJ, Hekster YA, Van der Meer JSUM. Optimizing antimicrobial therapy, a method for antimicrobial drug use evaluation. J. Antimicrob.Chemother 1992; 32:724-7

10. Fridkin SK, Gaynes RP. Antimicrobial resistance in intensive care units. Clinics Chest Med 1999; 20:30316. 